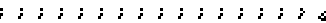

: Widya Akuntansi dan Keuangan

: Universitas Hindu Indonesia

Edisi Agustus 2020

\title{
Pengaruh Perekonomian Indonesia di Berbagai Sektor Akibat Corona Virus Disease 2019 (Covid-19) \\ Ni Ketut Muliati
}

Universitas Hindu Indonesia

Surel: $\underline{\text { Ketutmuli@yahoo.com }}$

\begin{abstract}
This research was carried out based on the covid-19 outbreak that is currently happening in Indonesia and in several countries. This pandemic is not only threatening public health and safety but also threatens the economic situation in various sectors. The research method used in this research is qualitative research, data collection techniques used in this study are library research techniques. Based on the results of the Bank Indonesia (BI) Business Activity Survey (SKDU) in Quarter I-2020 indicating a decline in the economy in various sectors. This can be seen from the Weighted Net Balance (WNB) value in the first quarter of 2020 amounting to $-5.56 \%$, which is quite deep compared to $7.79 \%$ in quarter IV-2019. The decrease was caused by the decrease in demand and supply due to co-19.
\end{abstract}

Keyword: economy, Covid-19, economic sector

\section{PENDAHULUAN}

Beberapa negara di dunia saat ini sedang menghadapi perang yaitu perang melawan virus yang sering disebut dengan covid-19 (Corona Virus Disease 2019). Sejak diumumkan covid-19 menjadi wabah atau pandemi global oleh World Healty Organisasion (WHO) tanggal 11 Maret 2020, covid-19 menjadi sangat menakutkan bagi semua Negara karena penyebarannya yang sangat cepat. Berdasarkan pengumuman WHO tersebut banyak Negara yang akhirnya melakukan tindakan untuk mencegah semakin banyaknya korban dari Covid19 dari menjaga jarak (Social distancing) sampai dengan lockdown (tidak boleh meninggalkan tempat tinggal sama sekali). Indonesia telah mengambil berbagai kebijakan seperti bekerja dari rumah, menjaga jarak, Pembatasan Sosial Berskala Besar (PSBB). Menurunya berbagai sektor ekonomi akibat virus corona.

Sektor pertanian merupakan kebutuhan pangan sehari-hari untuk memenuhi kebutuhan masyarakat, baik hasil pertanian pangan dan perkebunan, peternakan, sayuran dan buahbuahan. Apalagi mewabahnya Covid-19 ini menuntut masyarakat untuk meningkatkan imunitas dengan antara lain mengonsumsi makanan yang beragam dan bergizi. Meskipun 


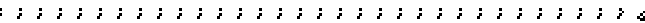

- Widya Akuntansi dan Keuangan

: Universitas Hindu Indonesia

Edisi Agustus 2020

demikian, kondisi saat ini justru menjadi sebuah dilema bagi sektor pertanian. Walaupun peluang pasar produk pangan tetap terbuka lebar tetapi distribusi hasil pertanian terkendala karena pembatasan sosial berskala besar (PSBB) dan social distancing. Hal ini menyebabkan lesunya permintaan dan menurunnya harga produk pertanian dan peternakan di masa panen raya.

Penurunan harga komoditas di Indonesia berkaitan dengan dampak virus corona di China. Hal ini dikarenakan China merupakan eksportir terbesar di dunia termasuk Indonesia. Kondisi di Indonesia dipenagaruhi oleh buruknya perdagangan di China, seperti adanya permintaan bahan baku di Cina. Terganggunya pasokan bahan baku sangat mempengaruhi para pelaku usaha yang akhirnya menutup usahanya sementara waktu karena ketidakmampuan membiayai kegiatan operasional perusahaan.

Penerimaan pajak juga mengalami penurunan akibat melemahnya kegiatan ekonomi dan harga minyak dunia yang terus turun. Pajak memiliki fungsi yaitu sebagai salah satu sumber dana pemerintahan pusat dan daerah untuk melaksanakan pembangunan. Penurunan pajak juga di perparah karena adanya perlambatan aktivitas ekonomi Pembatasan Sosial Berskala Besar (PSBB), pemberian stimulus dan fasilitas serta penurunan harga komoditas.

Sektor yang paling merasakan akibat dari virus corona adalah pariwisata. Saat ini sudah banyak Hotel dan restaurant yang menutup usahanya sementar waktu, baik dari kelas melati sampai dengan hotel berbintang karena tidak adanya pemasukan. Tempat wisata dan biro perjalanan juga melakukan hal yang sama. Padahal pariwisata merupakan penyumbang devisa terbesar bagi Negara. Seperti Bali, pemasukan utamanya adalah wisatawan dan china adalah penyumbang wistawan terbanyak. Akibat penurunan pendapatan sektor pariwisata, banyak terjadi Pemutusan Hubungan Kerja (PHK), sehingga menyebabkan penurunan penghasilan masyarakat dan menambah pengganguran.

Berdasarkan kondisi yang terjadi di Indonesia saat ini akibat Covid-19, maka peneliti tertarik untuk mengetahui pengaruh perekonomian Indonesia di berbagai sektor akibat corona virus disease 2019 (covid-19). Penelitian ini tergolong baru karena covid-19 dapat dikatakan sebagai fenomena baru yang sedang terjadi seluruh dunia termasuk Indonesia yang tidak saja mempengaruhi satu aspek saja tetapi sudah mempengaruhi perekonomian di berbagai sektor yang dapat mengancam kesejahteraan masyarakat. 


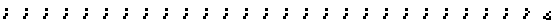

- Widya Akuntansi dan Keuangan

: Universitas Hindu Indonesia

Edisi Agustus 2020

\section{METODE}

Penelitian ini dilakukan bertujuan untuk mengetahui pengaruh Pandemi Corona Virus Disease 2019 (Covid-19) terhadap kondisi perekonomian Indonesia di beberapa sektor. Metode penelitian yang digunakan adalah penelitian bersifat kualitatif yaitu berupa penjelasan dan uraian yang diperoleh dari berbagai sumber literatur dan bacaan terkait pandemi Covid-19. Teknik pengumpulan data yang digunakan dalam penelitian ini adalah teknik pustaka (library research) yakni penelitian dilaksanakan dengan cara pencarian literatur (kepustakaan) baik berupa buku, catatan, jurnal, web (internet) dan juga informasi lainnya yang berhubungan dengan tema penelitian ini. Sumber data dalam penelitian ini adalah data sekunder berupa catatan, dokumen, jurnal, buku dan catatan yang berhubungan dengan penelitian ini.

\section{HASIL DAN PEMBAHASAN}

Virus corona (covid-19) pertama kali ditemukan di Wuhan, Provinsi Hubei, China. Sampai saat ini obat corona (covid-19) belum ditemukan dan korban semakin bertambah. Sudah 216 lebih negara di dunia melaporkan adanya kasus terpapar virus corona. Sampai dengan tanggal 20 juli 2020 total yang terkonfirmasi covid-19 berjumlah 88.214 orang, sembuh 46.977 dan meninggal berjumlah 4.239 orang (Covid19.go.id.2020). Semakin hari semakin banyak orang yang terpapar corona, hal ini disebabkan oleh salah satu faktor karena tidaknya ada kompensasi Negara menjadi penyebab ketidakpatuhan masyarakat, Sehingga masyarakat mengalami kesulitan secara ekonomi tapi mereka tidak boleh keluar rumah.

Virus ini jarang berevolusi dan menginfeksi manusia, namun wabah ini membuktikan bahwa bisa menyebar dari hewan ke manusia dan saat ini dapat menyebar dari manusia ke manusia (Halodoc.com.2020). Cara seseorang dapat terinpeksi covid-19 dengan melalui bantuk dan bersin, enyentuh area wajah dan tangan setelah memegang barang orang yang terpapar virus. Gejala yang muncul yaitu : Pilek, pusing, Batuk, tenggorokan sakit, Demam dan tidak enak badan. Upaya yang dilakukan guna mencegah virus menyebar adalah rajin mencuci tangan, jangan menyentuh area wajah, menyemprotkan disinpektan ke benda yang sering dipakai, menutup mulut dan hidung saat bersin dan batuk dengan tisu, kenakan masker dan pergi ke dokter apabila mengalami susah bernapas.

Menurut Baldwin dan Weder di Mauro (2020) menyatakan terdapat 3 faktor 'shock' yang dipicu oleh covid-19 sehingga bisa menimbulkan krisis ekonomi, Pertama covid-19 


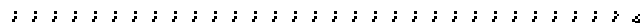

: Widya Akuntansi dan Keuangan

: Universitas Hindu Indonesia

Edisi Agustus 2020

mengakibatkan para pekerja harus dirawat di rumah sakit ataupun melakukan isolasi di rumah yang menyebabkan pengangguran sementara serta mempengaruhi pendapatan karena sebagian pekerja tidak dibayar saat sedang sakit. Kedua adalah upaya pencegahan dengan social distraction atau work from home mengakibatkan penutupan kantor, larangan bepergian, karantina, dan lainnya. Ketiga adalah expectations shock. Covid-19 menyebabkan kegiatan di seluruh dunia mengurangi aktivitasnya dan melihat yang akan terjadi. Ini menyebabkan berkurangnya jumlah perjalanan serta menurunnya tingkat hunian di hotel tetapi kemungkinan ini disebabkan oleh globalisasi yang menyebabkan berita itu terlalu cepat tersebar ke seluruh dunia. Baldwin (2020) membuat ilustrasi dampak covid terhadap perekonomian, seperti terlihat pada gambar dibawah ini :

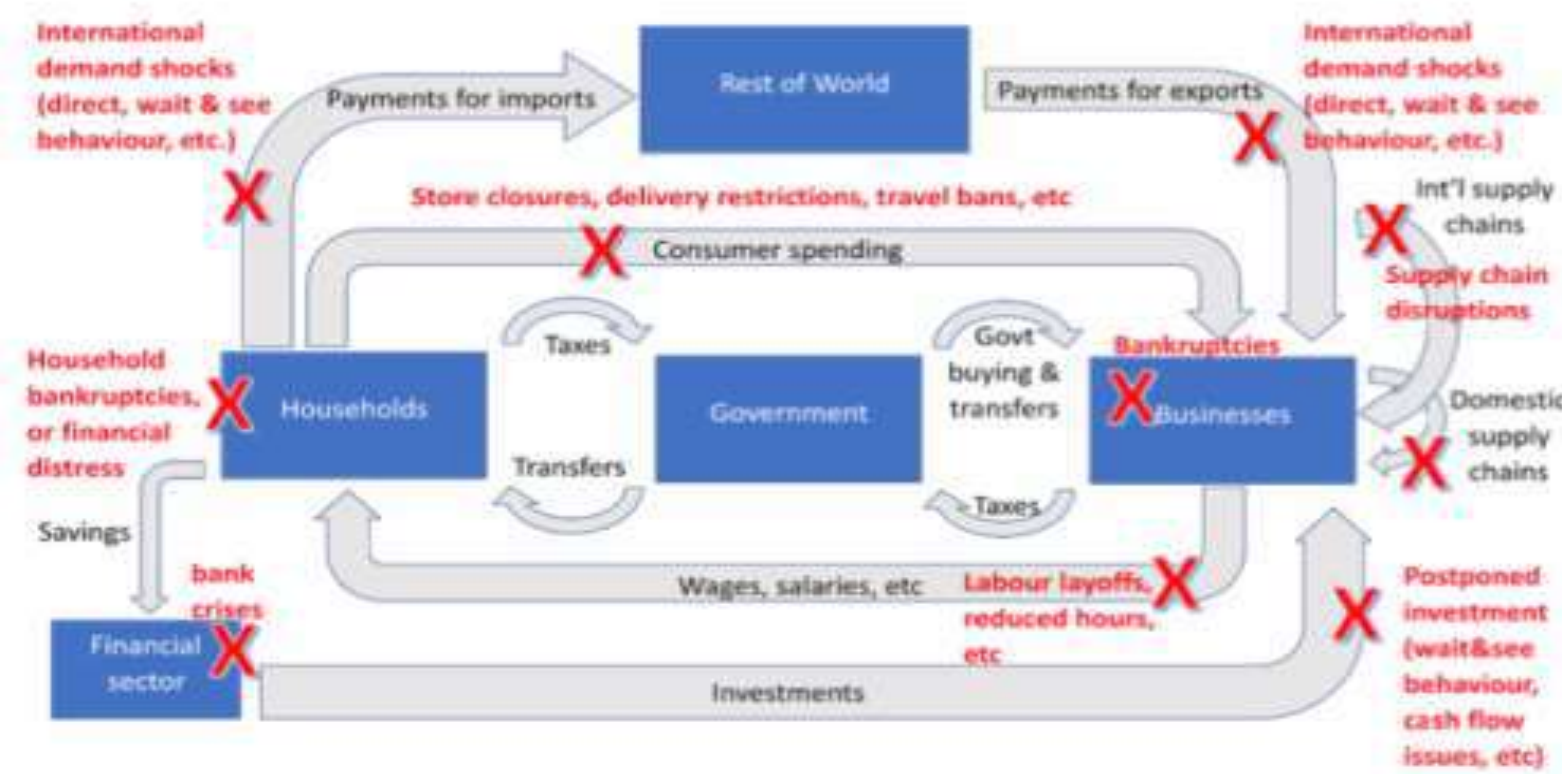

Gambar 1. Dampak Covid-19 terhadap Perekonomian

Sumber: Baldwin (2020)

Pandemi yang terjadi tidak hanya mengancam kesehatan dan keselamatan masyarakat tetapi juga mengancam keadaan ekonomi saat ini. Pemerintah sudah mengambil beberapa kebijakan (kompas.com.2020) yaitu:

a. Memotong rencana belanja yang bukan belanja prioritas dalam Anggaran Pusat dan daerah.

b. Pemerintah pusat dan daerah diminta untuk merevisi anggaran guna mempercepat pengentasan wabah. 


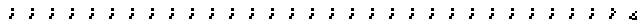

- Widya Akuntansi dan Keuangan

: Universitas Hindu Indonesia

Edisi Agustus 2020

c. Menjamin ketersediaan bahan pokok oleh di pusat dan daerah serta terjaganya daya beli masyarakat.

d. memperbanyak Padat Karya Tunai dengan tetap mematuhi aturan pencegahan virus.

e. Pemegang kartu sembako murah memberikan tambahan Rp 50.000 selama 6 bulan.

f. Mempercepat penggunaan kartu pra-kerja untuk mengantisipasi pekerja yang terkena PHK.

g. Membayarkan pajak penghasilan (PPh) Pasal 21 karyawan di industri pengolahan.

h. Memberikan relaksasi kredit di bawah Rp 10 miliar untuk UMK/Menengah (UMKM) oleh Otoritas Jasa Keuangan (OJK)

Berdasarkan hasil survei Bank Indonesia di Triwulan I-2020 mengindikasikan penurunan perekonomian di berbagai sektor. Hal ini ditunjukkan oleh Nilai Saldo Bersih Tertimbang (SBT) pada triwulan I-2020 senilai $-5,56$ persen mengalami penurunan senilai 7,79 persen di triwulan IV-2019. Penurunan tersebut disebabkan oleh turunnya permintaan dan pasokan akibat covid-19. Penjelasan penurunan ekonomi diberbagai sektor dapat dijelaskan sebagai berikut :

1. Sektor Pertambangan dan Penggalian

Sektor ini menunjukkan masih negatif senilai -0,62 persen di triwulan pertama tahun 2020 dibandingkan dengan triwulan sebelumnya -1,25 persen. turunnya harga minyak dunia serta tingginya curah hujan diprakirakan menjadi penyebab terbatasnya operasi.

2. Sektor Industri Pengolahan

Berdsarkan Saldo Bersih Tertimbang (SBT) sebesar -3,60 persen turun dari 0,76 persen di triwulan keempat tahun 2019. Secara keseluruhan penurunan diduga sebagai dampak menurunnya permintaan dan tidak lancaranya pasokan bahan baku.

3. Sektor Listrik, Gas dan Air Bersih

Sektor ini melambat di triwulan pertama tahun 2020 dengan SBT sebesar 0,21 persen lebih kecil dibandingkan sebelumnya SBT 0,31 persen.

4. Sektor Konstruksi

Sektor ini terindikasi tumbuh terkontraksi di triwulan pertama tahun 2020 dengan SBT sebesar $-0,08$ persen lebih kecil dari 0,66 persen pada periode sebelumnya. Lambatnya kegiatan usaha dikarenakan melemahnya permintaan proyek konstruksi/infrastruktur di dalam negeri. 


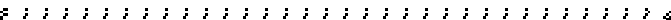

- Widya Akuntansi dan Keuangan

: Universitas Hindu Indonesia

Edisi Agustus 2020

5. Sektor Perdagangan, Hotel dan Restoran

Pada sektor ini terindikasi turun di triwulan pertama tahun 2020 dibandingkan periode sebelumnya yaitu SBT sebesar $-3,04$ persen lebih kecil dibandingkan 2,76 persen pada triwulan empat tahun 2019 .

6. Sektor Pengangkutan dan Komunikasi

Sektor ini menurun di triwulan pertama tahun 2020 sebesar $-0,53$ persen dibandingkan 1,06 persen pada triwulan empat tahun 2019.

7. Sektor Keuangan, Real Estate dan Jasa Perusahaan

Pada sektor ini melambat di triwulan pertama tahun 2020 SBT kegiatan usaha sebesar 1,13 persen, dibandingkan triwulan sebelumnya 3,01 persen pada triwulan empat tahun 2019.

8. Sektor Jasa-jasa

Pada sektor ini diperkirakan melambat di triwulan pertama tahun 2020 SBT kegiatan usaha sebesar 0,59 persen dibandingkan triwulan sebelumnya sebesar 2,51 persen.

9. Sektor Pertanian, Perkebunan, Peternakan, Kehutanan dan Perikanan Secara umum meningkat di triwulan pertama tahun 2020 Saldo Bersih Tertimbang (SBT) sebesar 0,40 persen, lebih besar dibandingkan -2,03 persen pada triwulan empat tahun 2019 peningkatan ini dikarenakan musim panen.

Abdi dan Burhanudin, (2020) menyatakan covid-19 juga berdampak terhadap ekonomi global di 3 sektor yaitu :

1. Sektor Pasar Modal

Para investor di pasar saham modal telah dibuat panik oleh covid-19. Pasar ekuitas global bergerak sangat tinggi yang terlihat dari indeks volatilitas (VIX) keluaran Chicago Board Options Exchange berada di level tertingginya selama 5 tahun. Covid-19 juga membuat investor pasar modal mengalami kepanikan yang mempengaruhi keputusan investasi sehingga dampaknya begitu signifikan dan membuat pasar modal mendapat tekanan yang keras. Epidemi penyakit menular akan menyebabkan kerugian ekonomi yang tercermin dalam pergerakan harga saham (Jiang, Y., dkk,2017).

\section{Perdagangan Surat Utang}

Dalam sejarah surat utang AS bertenor 10 tahun berada di level terendahnya yaitu berada di level $0,7070 \%$ pada Jumat (6/3/2020). Hal ini berarti investor tidak tertarik 


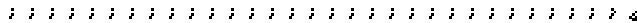

- Widya Akuntansi dan Keuangan

: Universitas Hindu Indonesia

Edisi Agustus 2020

dengan surat hutang yang dikeluarkan oleh AS dalam 3 tahun terakhir dan pengambilan keputusan ini terjadi saat covid-19. Terjadinya covid-19 telah melahap sektor ekonomi AS dengan sangat kuat.

\section{Perdagangan Emas}

Lonjakan perdagangan emas terus meningkat saat terjadinya Covid-19. hal ini membuat harga emas semakin meningkat dan mencapai nilai tertinggi dalam 7 tahun terakhir. Saat ini emas menjadi investasi yang sangat diminati dimana semula emas hanya dikatagorikan sebagai investasi yang minimum resiko.

Perekonomian Indonesia sebuah negara bertujuan untuk pemerataan distribusi pendapatan dan mencapai kemakmuran masyarakat. Berbeda dengan keadaan yang terjadi tahun 1997/1998 dimana krisis yang terjadi adalah nilai tukar uang kemudian berkembang menjadi krisis perbankan sampai terjadi krisis sosial dan politik yang berdampak besar pada bangsa Indonesia. Penyebab terjadinya krisis yang berkepanjangan adalah sistem ekonomi pasar bebas menyababkan orang bebas untuk bertindak melakukan terbaik bagi dirinya dan lemahnya sistem perbankan. Terdapat dua kelompok yang mengatakan krisis muncul karena terdapat kelemahan struktur didalam sistem keuangan maupun perbankan (Djiwandono,2001), kelompok pertama sebagai internationalists sedangkan kelompok kedua sebagai fundamentalists. Kasus yang terjadi di Indonesia terdiri dari unsur eksternal berupa kepanikan keuangan dan lemahnya ekonomi nasional baik sektor perbankan maupun

riil, ketika gejola eksternal muncul, perekonomian eksternal yang lemah sangat mudah terkena dampaknya sehingga dalam waktu yang singkat berubah menjadi krisis ekonomi.

Meningkatnya jumlah penderita dengan tingkat kematian yang tinggi akibat covid-19 saat ini sangat meresahkan. Upaya pemerintah untuk mencegah penularan dengan melakukan penutupan sekolah, bekerja dari rumah, terutama pekerja sektor formal, keterlambatan dan pembatalan dari berbagai acara pemerintah dan swasta membuat ekonomi global menurun (Ramelli \& Wagner, 2020). Dampak dari covid-19 menimbulkan kerentanan terhadap ekonomi (Leiva-Leon, et al, 2020). Beberapa pendapat berharap bahwa efek menjadi terbatas terutama untuk Cina, tapi skala dan kecepatan dari pengembangan covid19 telah berdampak pada ekonomi global (Ayittey et al 2020). Penjualan di pasar tradisional ataupun modern dipastikan akan turun. Padahal, sebelum covid-19 teridentifikasi di Indonesia, data Indeks Penjualan Riil dirilis oleh Bank Indonesia sudah menunjukkan kontraksi 0,3\% pada Januari 2020 (Muzakki, 2020). 


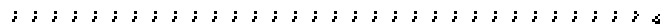

- Widya Akuntansi dan Keuangan

: Universitas Hindu Indonesia

Edisi Agustus 2020

Covid-19 memberikan dampak pada perekonomian Indonesia pada jangka pendek yaitu menurunnya harga saham pada sector finance dan trade yang menyebabkan kerugian, sedangkan jangka panjang akan mempengaruhi cashflow perusahaan terutama di sector trade dengan menurunya jumlah orang yang bepergian. Hal ini juga akan berdampak pada sektor perbankan karena umumnya perusahaan menjalankan usahanya menggunakan dana pinjaman bank. Hal ini akan terlihat dengan potensi meningkatnya Non Performance Loans (NPL) dari perbankan nasional.

\section{SIMPULAN DAN SARAN}

Berdasarkan hasil pembahasan diatas maka dapat disimpulkan bahwa hasil survei Bank Indonesia di Triwulan I-2020 mengindikasikan penurunan perekonomian di berbagai sektor. Hal ini ditunjukkan oleh Nilai Saldo Bersih Tertimbang (SBT) pada triwulan I-2020 senilai $-5,56$ persen mengalami penurunan senilai 7,79 persen di triwulan IV-2019. Penurunan tersebut disebabkan oleh turunnya permintaan dan pasokan akibat covid-19. Hampir semua sektor mengamalami penurunan yaitu Sektor pertambangan dan perdagangan sektor industri, Sektor Konstruksi, Sektor Listrik, Gas dan Air Bersih, Sektor Perdagangan, Hotel dan Restoran, Sektor Pengangkutan dan Komunikasi, Sektor Keuangan, Real Estate dan Jasa Perusahaan, Sektor Jasa-jasa, kecuali sektor Sektor Pertanian, Perkebunan, Peternakan, Kehutanan dan Perikanan mengalami peningkatan disebabkan oleh musim panen. Ekonomi secara global juga mengalami dampak dari covid-19 yaitu Sektor Pasar Modal, Perdagangan Surat Utang mengalami penurunan tetapi Perdagangan Emas justru mengalami peningkatan dalam tujuh tahun terakhir. Melihat dampak yang ditimbulkan oleh Wabah covid-19 ini, maka sebaiknya masyarakat mengikuti semua himbauan yang berikan oleh pemerintah guna memutus mata rantai covid-19.

\section{DAFTAR PUSTAKA}

Abdi, M. N. (2020). Krisis Ekonomi Global dari Dampak Penyebaran Virus Corona (Covid19). AkMen Jurnal Ilmiah, 17(1), 90-98.

Ade Novalina.,Rusiadi. (2020).Indonesian economy the impact of covid-19 (ihsg by ardl). Jurnal Kajian Ekonomi dan Kebijakan Publik, Vol. 5 No. 2 Juli 2020, 2527-2772.

Amalia, Citra. (2020). Social Distancing: Menjaga Jarak Antar Manusia, Mendekatkan Diri kepada Allah SWT. Diakses dari https://percikaniman.id/2020/03/16/socialdistancing-adalah pada tanggal 12 Juni 2020. 
Ayittey, F. K., Ayittey, M. K., Chiwero, N. B., Kamasah, J. S., \& Dzuvor, C. 2020. Economic impacts of Wuhan 2019-nCoV on China and the world. Journal of Medical Virology, 92(5), 473-475.

Baldwin, R., (2020), "Keeping the lights on: Economic medicine for a medical shock", VoxEU.org, 13 March.

Bank Indonesia. 2020. Survei Kegiatan Dunia Usaha (https://www.bi.go.id/id/publikasi/survei/kegiatan-dunia-usaha/Pages/skdutriwulan-I- 2020.aspx, diakses 15 Mei 2020

Budastra, I. K. (2020). Dampak sosial ekonomi covid-19 dan program potensial untuk penanganannya: studi kasus di kabupaten lombok barat. Jurnal agrimansion, 21(1), $48-57$.

Fadli, Rizal.(2020). Corona virus (https://www.halodoc.com/kesehatan/coronavirus), diakses 15 Juni 2020.

Febriyani Nurul dan Rahmadia Shinta.(2020). Dampak Covid-19 terhadap ekonomi. Academia.edu.

Gugus Tugas Percepatan Penanganan Covid-19.2020. Peta Sebaran. (https://covid19.go.id/petasebaran, diakses: 20 Juli 2020

Hanoatubun, S. (2020). Dampak Covid - 19 terhadap Prekonomian Indonesia. EduPsyCouns: Journal of Education, Psychology and Counseling, 2(1), 146-153. Retrieved from https://ummaspul.e-journal.id/Edupsycouns/article/view/423

Jiang, Y., Zhang, Y., Ma, C., Wang, Q., Xu, C., Donovan, C., Ali, G., Xu, T., \& Sun, W. (2017). H7N9 not only endanger human health but also hit stock marketing. Advances in Disease Control and Prevention, 2(1), 1-7, DOI:10.25196/adcp201711

Kompas. 2020. 9 Kebijakan Ekonomi Jokowi di Tengah Pandemi Covid-19: Penangguhan Cicilan hingga Relaksasi Pajak, (https://nasional.kompas.com/read/2020/03/26/07412441/9-kebijakan-ekonomijokowi-di-tengah-pandemi-covid-19-penangguhan-cicilan?page=all. Diakses 10 April 2020.

Leiva-Leon, D., Pérez-Quirós, G., \& Rots, E. 2020. Real-time weakness of the global economy: a first assessment of the coronavirus crisis.

Maryanti, S., Netrawati, I. G. A. O., \& Nuada, I. W. (2020). Pandemi covid-19 dan implikasinya pada perekonomian ntb. Media bina ilmiah, 14(10), 3497-3508.

Muzakki, F. 2020. The Global Political Economy Impact of Covid-19 and The Implication to Indonesia. Journal of Social Political Sciences, 1(2), 76-92.

Ramelli, S., \& Wagner, A. F. 2020. Feverish stock price reactions to the novel Coronavirus. Available at SSRN 3550274.

Suara Merdeka. 2020. Ekonomi di masa pandemi covid-19. (https://www.suaramerdeka.com/news/opini/225802-ekonomi-di-masa-pandemicovid-19), diakases 28 Mei 2020. 